power is a dominant one which can be asserted to the exclusion of any competing or conflicting one. The power is . . "a dominant servitude" . . "a superior navigation easement." $" 21$

Under this view of the case any time the government had the power to regulate use of property, that power would automatically create a property right in the government. Take, for example, land especially valuable as a site for a liquor store, which, of course, requires a state license. If the state decided to establish a system of state liquor stores it could take the land at a reduced price under the theory that, as to this use, its licensing power had given it a prior property right. This would apparently be the case even though the bill which provided for the licensing power was not intended to give the state any "property rights" but was intended only to allow regulation of certain types of commerce. Furthermore, since Douglas did not argue from the Federal Power Act, but directly from the Commerce Clause itself, presumably no enacting statute would be required. This rather surprising extension of regulatory powers is far beyond the originally intended scope of these powers. It is difficult to see what it accomplishes other than allowing the government to take certain lands at bargain prices.

As the Fifth Amendment proscribes the government from taking land at bargain prices so does the power of eminent domain, which inures in every sovereign, allow it to obtain needed land without paying a hold-up value. In an economy based on private enterprise the use of such extra-economic power should be exercised so that it has as little effect as possible on the workings of legitimate economic factors. This can only be done by application of the traditional market value standard. Continued application of the $T$ win City rule will not only discourage expenditures for private power development, but it will also place the cost of land acquisition for any power development on the present owners of suitable land rather than on consumers or taxpayers where the burden properly belongs.

${ }^{21}$ United States v. Twin City Power Co., 350 U.S. 222, 224-25 (1956).

\title{
STRANGER ATTACK ON SISTER-STATE DECREES OF DIVORCE
}

Perplexing doctrinal difficulties are presented by the problem of stranger ${ }^{1}$ attack $^{2}$ on sister-state decrees of divorce. Given a finding by the divorce court

"A "stranger" in this context is a third party who, though neither party nor privy, has some right or interest which is affected by the purported dissolution of a marital status; for example, a subsequent spouse, a legatee of a subsequent spouse, a tenant of a party, or a sister state in which a party is domiciled. Consult note 2 infra.

${ }^{2}$ Attack may be waged in various ways, and may be initiated by the moving party or introduced as a defense. E.g., Cook v. Cook, 342 U.S. 126 (1951) (action for annulment by subsequent spouse); In re Estate of Day, 7 Ill. 2d 348, 131 N.E. 2d 50 (1955) (probate of will by legatee of subsequent spouse); Williams v: North Carolina II, 325 U.S. 226 (1945) (crimina] 
that plaintiff was domiciled ${ }^{3}$ within the jurisdiction, two phenomena may result. First, if the finding of domicile is unimpeachable in the forum in which attack is waged, either because it cannot be demonstrated to be erroneous ${ }^{4}$ or cannot be reopened, ${ }^{5}$ then strangers are bound by the divorce decree. And yet, the notion that divorce is a proceeding in rem, i.e., "binding on the whole world," has been discredited of late. ${ }^{7}$ Second, if the forum of attack finds that the issue of domicile was incorrectly decided, stranger attack will succeed if the divorce proceedings were ex parte, ${ }^{8}$ apparently on the theory that domicile is a constitutional prerequisite for full faith and credit. ${ }^{9}$ But if the divorce proceedings were bilateral, ${ }^{10}$ then strangers are precluded from showing what might otherwise be a fatal absence of domicile. ${ }^{11}$ The ex parte-bilateral distinction makes sense with respect to party attack because of the opportunity to litigate in the original proceedings, ${ }^{12}$ but it is less easy to rationalize when applied to strangers. The ex parte situation may be explained by the view that divorce is a proceeding in rem, for even a judgment in rem may be collaterally attacked for jurisdictional

action for bigamous cohabitation); Cheever v. Wilson, 9 Wall. (U.S.) 108 (1869) (action by defendant spouse against tenant of plaintiff spouse to recover rents).

${ }^{3}$ As used hereinafter, "domicile" refers to the divorce court's finding on the issue of plaintiff's domicile, not to the absolute fact of domicile. Although it seems that a finding that defendant is domiciled within the divorce state would be sufficient, no case has been located which involves this precise question.

4 See Williams v. North Carolina II, 325 U.S. 226, 227 (1945).

5 Cook v. Cook, 342 U.S. 126, 128 (1951). Cf. Johnson v. Muelberger, 340 U.S. 581, 589 (1951).

62 Freeman, Judgments $\$ 906$ (5th ed., 1925).

${ }^{7}$ Williams v. North Carolina II, 325 U.S. 226, 232 (1945); Williams v. North Carolina I, 317 U.S., 287, 297 (1942); Haddock v. Haddock, 201 U.S. 562, 576 (1906). The traditional view is stated in the dissent in Haddock v. Haddock, supra, at 624, and in 2 Bishop, Marriage and Divorce $\$ 164$ (4th ed., 1896).

${ }^{8}$ Williams v. North Carolina II, 325 U.S. 226 (1945). The court in Hopson v. Hopson, 221 F.2d 839, 842 n.4 (App. D.C., 1955), defines an "ex parte" proceeding as "one in which there had been neither personal service of process nor voluntary appearance or participation by the spouse sued." Justice Jackson, dissenting in Rice v. Rice, 336 U.S. 674, 678 (1949), declared, "To me ex parte divorce is a concept as perverse and unrealistic as an ex parte marriage."

9 Williams v. North Carolina II, 325 U.S. 226, at 227, 229 (1945). When the decree of divorce is that of a foreign country, where the doctrine of comity and not that of full faith and credit applies, the absence of a finding of domicile will not preclude its validity in the attack forum. Drew v. Hobby, 123 F.Supp. 245, 248 (S.D.N.Y., 1954): "It is not offensive to the public policy of New York to recognize, despite the absence of the 'jurisidctional fact' of domicile, a foreign divorce obtained by parties to a marriage who have taken the marital res out of the state for the purpose of invoking a divorcing jurisdiction, by the actual appearance of one ... coupled with the voluntary appearance of the other through authorized counsel."

${ }^{10} \mathrm{~A}$ bilateral divorce is a proceeding wherein the divorce court has personal jurisdiction over the defendant spouse.

il Cook v. Cook, 342 U.S. 126 (1951).

${ }^{12}$ Coe v. Coe, 334 U.S. 378 (1948); Sherrer v. Sherrer, 334 U.S. 343 (1948). 
defect. ${ }^{13}$ But since appearance by the defendant in the divorce proceedings wholly precludes a stranger from demonstrating lack of domicile, the result is to clothe the bilateral decree with an impregnability greater than the typical judgment in rem.

The purpose of this comment is to examine the law of stranger attack on sister-state decrees of divorce, in order to develop a legal framework upon which to base the results of present-day case law, ${ }^{14}$ and by which the answers to unsettled questions may be predicted with a fair degree of certainty. ${ }^{15}$ Although it has been accurately stated that analysis of the problem is not promoted by labelling a suit for divorce an action in rem, ${ }^{16}$ some precision in describing the limits of the needed framework may be reached by measuring the effect of ex parte and bilateral decrees against the effect of judgments in rem, as well as in personam.

Ex parte divorce. The binding effect of an ex parte decree in another state is dependent upon whether or not a litigant can persuade the forum of attack that the finding of domicile by the divorce court was incorrect. ${ }^{17}$ Notwithstanding the receipt of proof against this finding, if the heavy burden ${ }^{18}$ of overturning it is not sustained, then full faith and credit is mandatory and stranger attack in the other state cannot succeed..$^{19} \mathrm{~A}$ minority of jurisdictions even withhold the

${ }^{13}$ Rest., Judgments $\$ 73$, Comment a (1942): "The judgment [in rem] is not subject to collateral attack by anyone, unless the judgment was void because the court did not have jurisdiction over the thing or was not competent to render the judgment or there was a failure to give proper notice and opportunity to be heard." Compare ibid., \$74, Comment a. Consult authorities cited note 21 infra.

${ }^{14}$ The absence of a satisfactory legal framework is manifest in Cook v. Cook, 342 U.S. 126 (1951); language there epitomizes the difficulty of analysis in this area of the law. Consult text at note 48 infra.

${ }^{15}$ The major unsolved problem, whether a state can impeach a sister-state bilateral decree of divorce, is discussed at 387 infra.

${ }^{16}$ See, e.g., Williams v. North Carolina I, 317 U.S. 287, 297 (1942).

17 Williams v. North Carolina II, 325 U.S. 226 (1945).

${ }^{18}$ Williams v. North Carolina II, 325 U.S. 226, 233-34 (1945) ("The burden of undermining the verity which the Nevada decrees import rests heavily upon the assailant."). But Justice Black, dissenting at 275 , felt that the burden should be much heavier. For illustrations of the burden, see Rice v. Rice, 336 U.S. 674 (1949); Commonwealth v. Petrosky, 168 Pa.Super. 232, 77 A.2d 647 (1951); Patterson v. Patterson, 208 Ga. 7, 64 S.E.2d 441 (1951); Ludwig v. Ludwig, 413 Ill. 44, 107 N.E.2d 848 (1952).

${ }^{19}$ The fullness of the faith and credit due an ex parte decree founded on an unimpeachable determination of plaintiff's domicile is pointed up by the holding in Williams v. North Carolina I, 317 U.S. 287 (1942). So long as the defendant spouse remains its domiciliary the attacking state has an interest in the marital status at least equivalent to that of the divorce state, but the full faith and credit clause commands that the attacking state smother its protests.

"The very function of the [full faith and credit] clause is to compel the states to give effect to the contrary policies of other states when these have been validly embodied in judgment. ... The foreclosure was not intended only for slight differences or for unimportant matters. It was also meant for the most important ones. The Constitution was not dealing with puny matters. ..." Williams v. North Carolina II, 325 U.S. 226, 254 (1945) (Rutledge, J., dissenting). Cf. Fauntleroy v. Lum, 210 U.S. 230 (1908). 
opportunity to re-litigate the issue of domicile unless the stranger's interest in the marital res or status matured prior to the decree sought to be overthrown. ${ }^{20}$ The justification for this conclusive effect with respect to strangers may be found in the theory of actions in rem generally-the notion that some disputes need to be settled finally notwithstanding the lack of personal jurisdiction over all claimants to the res. ${ }^{21}$ Thus, it was early held that legislative ${ }^{22}$ and judicial ${ }^{23}$ termination of marriage without personal jurisdiction over the defendant spouse does not unjustly deprive him of his interest in the marital status. And since it is difficult to imagine a case in which a defendant spouse would possess less interest in the marital status than a stranger, it seems, a fortiori, that there is no injustice to the stranger.

When the assailant sustains the requisite burden, Williams v. North Carolina $I I^{24}$ holds that the courts of a sister state may reject ${ }^{25}$ the divorce forum's finding of domicile without violating the constitutional mandate of full faith and credit. ${ }^{26}$ Whereas the attack in Williams $I I$ was launched by a sister state, it seems clear in reference to ex parte divorces that there are no significant distinctions among the various possible assailants of the decree which may operate

${ }^{20}$ See Gaylord v. Gaylord, 45 So.2d 507 (Fla., 1950). Cases are instructively collected in Old Colony Trust Co. v. Porter, 324 Mass. 581, 589, 88 N.E.2d 135, 140 (1949) (Qua,C.J.). Consult 1 Freeman, Judgments $\$ \$ 319,636$ (5th ed., 1925); The Dilemma of Third Party Attack Upon Foreign Divorces, 17 Brooklyn L. Rev. 70, 72-73 (1950).

21 Consult Rest., Judgments \$2, Comments a and b (1942).

22 Maynard v. Hill, 125 U.S. 190 (1888).

${ }^{23}$ Atherton v. Atherton, 181 U.S. 155 (1901). But cf. Haddock v. Haddock, 201 U.S. 562 (1906) (collecting the early cases), which was expressly overruled by Williams v. North Carolina I, 317 U.S. 287 (1942).

24325 U.S. 226 (1945).

${ }_{25}$ The attack forum's rejection is reviewable by the Supreme Court as a federal question involving full faith and credit. Williams v. North Carolina II, 325 U.S. 226, 233 (1945).

26 Justice Rutledge, dissenting in Williams v. North Carolina II, 325 U.S. 226, 267 (1945), feared that this result would give rise to the anomaly thought to exist subsequent to Haddock v. Haddock, 201 U.S. 562 (1906), i.e., parties divorced in the divorce state and still married in the attack state. But a subsequent case requiring full faith and credit to the attacking judgment has proved the anxiety ill-founded. Sutton v. Leib, 342 U.S. 402, 408 (1952): The New York (impeaching) "decree is entitled to full faith throughout the Nation, in Nevada [divorce state] as well as in Illinois."

The necessity of a finding of domicile is also raised by a line of cases involving bilateral decrees which do not purport to rest on a finding of domicile. Consult discussion 385-86 infra. These cases indicate that such a decree is not entitled to full faith and credit and therefore does not bind strangers-at least where the divorce state has no interest other than mere physical presence of the parties. A fortiori this would be true of the ex parte situation. However, even if domicile is discarded (either wholly or in special circumstances) as a basis for jurisdiction in bilateral cases, it is unlikely that an extension of this innovation to ex parte cases would be permitted. In effect, such an extension would be contra to Williams v. North Carolina II, 325 U.S. 226 (1945), for it is difficult to comprehend how a decree not purporting to be based on domicile can have a greater effect than a decree which does so purport, although erroneously. Further, the suggested extension would result in what may be deemed an undesirable state of affairs: any spouse could obtain a divorce in any state which would be entitled to full faith and credit in every other state. 
to permit attack by one and preclude it by another. ${ }^{27}$ Thus, where a defendant spouse can succeed in collateral attack, ${ }^{28}$ so also can a subsequent spous ${ }^{29}$ or another state $;^{30}$ and where a defendant spouse cannot succeed, ${ }^{31}$ neither can a subsequent spouse ${ }^{32}$ or another state. ${ }^{33}$

Throughout, the Achilles' heel is the same jurisdictional defect-an impeachable finding of domicile-and where the finding of domicile is unimpeachable so that the defendant spouse is bound by the foreign ex parte decree of divorce, strangers-including a state-are likewise bound. Consequently, notwithstanding the absence from the divorce proceeding of anything comparable to the minimum requirement of constructive notice to strangers applicable to in rem proceedings, the ex parte decree of divorce is similar to the latter in its conclusive effect. ${ }^{34}$

${ }^{27}$ Note, however, the minority rule that to have standing to attack a stranger's interest must have accrued prior to the purported dissolution of the marital status. Consult authorities note 20 supra.

${ }^{28}$ Rice v. Rice, 336 U.S. 674 (1949); Ryan v. Ryan, 230 F.2d 838 (App. D.C., 1956); Ludwig v. Ludwig, 413 Ill. 44, 107 N.E.2d 848 (1952); Ulrey v. Ulrey, 231 Ind. 63,106 N.E.2d 793 (1952). The same is true, of course, with respect to privies. E.g., In re Veltri's Estate, 202 N.Y. Misc. 401, 113 N.Y.S.2d 146 (Surr. Ct., 1952) (attack by step-children).

${ }^{29}$ Jackson v. Jackson, 274 App.Div. 43, 79 N.Y.S.2d 736 (1st Dep't, 1948). Where the finding of domicile is vulnerable, however, an attack by the subsequent spouse may be turned back if defendant can show that the subsequent spouse either helped to procure the divorce or knowingly relied upon it when he married one of the parties to the divorce. Estate of Coleman, 132 Cal.App.2d 137, 281 P.2d 567 (1955) (heirs of subsequent spouse prevented from attacking the divorce decree as privies to the subsequent spouse who would himself have been estopped). An interesting approach to the establishment of such an estoppel against the subsequent spouse is suggested in Watkinson v. Watkinson, 67 N.J.Eq. 142, 157, 58 Atl. 384, 390 (Ch., 1904), where the duty of a subsequent spouse to investigate the competency of his intended mate to join with him in the execution of a marriage contract was likened unto the duty of a land-title examiner. And see Woodhouse v. Woodhouse, 11 N.J. 225, 94 A.2d 301 (1953).

${ }^{30}$ Williams v. North Carolina II, 325 U.S. 226 (1945); Long v. State, 5 Ter.(Del.) 262, 65 A.2d 489 (1949); State v. Nixon, 4 Ter.(Del.) 318, 46 A.2d 874 (1946); State v. Najjar, 1 N.J. Super. 208, 63 A.2d 807 (1949), aff'd 2. N.J. 208, 66 A.2d 37 (1949) (Mexican "mail-order" divorce). No case has been found illustrating an attack by a non-domiciliary state. The reason for this may perhaps be found in Williams v. North Carolina I, 317 U.S. 287, 298-99 (1942), and in Williams v. North Carolina II, 325 U.S. 226, 241-42 (1945), to the effect that an attacking state's interest in the marital res has its genesis in domicile.

${ }^{31}$ E.g., Zieper v. Zieper, 14 N.J. 551, 103 A.2d 366 (1954). The only relief available to the divorced spouse is found in the growing doctrine of divisibility, which is designed to protect personal rights, in contradistinction to rights in rem, in the marital status. Armstrong v. Armstrong, 350 U.S. 568 (1956); May v. Anderson, 345 U.S. 528 (1953); Estin v. Estin, 334 U.S. 541 (1948) (leading case); Kreiger v. Kreiger, 334 U.S. 555 (1948); Ryan v. Ryan, 230 F.2d 838 (App. D.C., 1956); Meredith v. Meredith, 226 F.2d 257 (App. D.C., 1955); Hopson v. Hopson, 221 F.2d 839 (App. D.C., 1955). But some courts are inclined to the view that the absent defendant spouse must have commenced his action in personam prior to the rendition of the decree of divorce. Anglin v. Anglin, 211 Miss. 405, 51 So.2d 781 (1951); Proper v. Proper, 102 Cal.App.2d 612, 228 P.2d 62 (1951); Shain v. Shain. 324 Mass. 603, 88 N.E.2d 143 (1949). Consult Morris, Divisible Divorce, 64 Harv. L. Rev. 1287 (1951).

${ }^{32}$ See Jackson v. Jackson, 274 App.Div. 43, 44-45, 79 N.Y.S.2d 736, 738 (1st Dept., 1948). 33 Williams v. North Carolina I, 317 U.S. 287 (1942).

${ }^{34}$ Consult authorities note 13 supra. 
Bilateral divorce. Analysis of stranger attack on sister-state bilateral decrees of divorce produces a rather startling conclusion. It was early established that domicile of the plaintiff spouse and personal appearance by the defendant spouse were sufficient to entitle the decree to full faith and credit elsewhere, even as to strangers. ${ }^{35}$ Today, however, a finding of domicile coupled with personal appearance by the defendant spouse will operate to preclude collateral attack whether by a party, ${ }^{36}$ privy ${ }^{37}$ or stranger, ${ }^{38}$ and irrespective of whether or not the finding of domicile might otherwise be subject to impeachment. ${ }^{39}$ The would-be assailant of a bilateral decree based on a finding of domicile is bound thereby and given no opportunity to attack for lack of domicile. In sharp contrast is the ex parte situation, where the assailant is given an opportunity in the

${ }^{35}$ In Cheever v. Wilson, 9 Wall.(U.S.) 108 (1869), W moved from the District of Columbia to Indiana and instituted a suit for divorce in which $\mathrm{H}$ appeared and denied all her allegations. Indiana granted W a divorce and ordered that some rents from certain of W's property be paid to $\mathrm{H}$. In an action on the decree in the District of Columbia, $\mathrm{T}$, defendant tenant of that portion of W's property, refused to pay $\mathrm{H}$, but not expressly on the ground of the invalidity of the divorce decree. Held for $\mathrm{H}$.

${ }^{36}$ Coe v. Coe, 334 U.S. 378 (1948) (appeared and admitted domicile); Sherrer v. Sherrer, 334 U.S. 343 (1948) (appeared and entered a general denial); Davis v. Davis, 305 U.S. 32 (1938) (appeared and contested domicile). Cf. Baldwin v. Iowa State Traveling Men's Ass'n, 283 U.S. 522 (1931). A special appearance to contest jurisdiction is sufficient to confer personal jurisdiction upon the court. E.g., Cherry v. Cherry, 208 Ga. 213, 65 S.E.2d 805 (1951), aff'd 208 Ga. 726, 69 S.E.2d 252 (1952). Contra: Davis v. Davis, 259 Wis. 1, 47 N.W.2d 338 (1951), where the court used the distinction in Staedler v. Staedler, 6N.J. 380, 78 A.2d 896 (1951), i.e., physical presence, whereas the accepted distinction, Johnson v. Muelberger, 340 U.S. 581, 587 (1951), is opportunity to contest. Consult Swanson, Migratory Divorce: Sherrer v. Sherrer and the Future, 18 Nev. S. B. J. 81 (1953).

${ }^{37}$ Johnson v. Muelberger, 340 U.S. 581 (1951) (attack by children of party). But consult 1 Freeman, Judgments $\$ 481$ (5th ed., 1925), for the view that children are not customarily considered to be in privity with their parents. Consult Standing of Children To Attack Their Parents Divorce Decree, 50 Col. L. Rev. 833 (1950), for the argument against permitting such attack. The Supreme Court held in the Johnson case that the law of the divorce forum should describe the limits of privity, within the boundaries of due process of law. Consult Toward Certainty in the Extraterritorial Effect of Divorce Decrees, 61 Yale L. J. 238 (1952).

${ }^{38}$ Cook v. Cook, 342 U.S. 126 (1951) (subsequent spouse); Taylor v. Taylor, 229 S.C. 92 , 91 S.E.2d 876 (1956) (subsequent spouse); In re Estate of Day, 7 Ill.2d 348, 131 N.E.2d 50 (1955) (legatee of subsequent spouse); Tierney v. Tierney, 332 Mass. 414, 125 N.E.2d 413 (1955) (subsequent spouse); Dietrich v. Dietrich, 41 Cal.2d 497, 261 P.2d 269 (1953) (subsequent spouse); DuPont v. DuPont, 8 Ter.(Del.) 231, 90 A.2d 468 (1952) (subsequent spouse); Widera v. Widera, 200 N.Y.Misc. 753, 113 N.Y.S.2d 127 (S. Ct., 1952) (subsequent spouse); Kienle v. Kienle, 201 N.Y.Misc. 948, 107 N.Y.S.2d 239 (S. Ct., 1951) (subsequent spouse). Consult Lenhoff, Attacks on Vulnerable Foreign Divorces: Outposts of Resistance, 21 N.Y.U. L. Q. Rev. 457 (1947); Jacobs, Attack on Decrees of Divorce by Second Spouses, 15 N.C. L. Rev. 136 (1937); The Dilemma of Third Party Attacks upon Foreign Divorces, op. cit. supra. note 20 .

${ }^{39}$ The important qualification stated in Johnson v. Muelberger, 340 U.S. 581, 587 (1951), and in Cook v. Cook, 342 U.S., 126, 128 (1951), to the effect that collateral attack may succeed if the divorce state would allow such attack, seems to have little force in practice because a state which is in the divorce-mill business would simply be decreasing the value of its divorce decrees by making them vulnerable. Consult, Toward Certainty in the Extraterritorial Effect of Divorce Decrees, op. cit. supra note 37; Migratory Divorce, 2 Law \& Contemp. Prob. 298 (1935) (symposium); Conference on Divorce, 9 U. of Chi. Conference Series (1952). 
forum of attack to impeach the divorce court's finding of domicile, as is true of actions in rem generally. ${ }^{40}$ Thus, this jurisdiction "in statum" effectuates a decree with greater conclusiveness than the traditional judgment in rem.

This finality is the effect of the Supreme Court's decision in Cook v. Cook. ${ }^{41}$ In that case, Mr. Cook (H-2) brought an annulment action in Vermont alleging that Mrs. Cook (W) was still married to Mr. Mann (H-1). The solution to this question rested on the effect to be given to a Florida decree purporting to divorce $\mathrm{W}$ from $\mathrm{H}-1$. This decree recited that $\mathrm{W}$ was domiciled in Florida, but $\mathrm{H}-2$ argued that such determination was in fact erroneous. ${ }^{22}$ The facts were such that the Vermont courts could reasonably believe H-2's contention that W was not domiciled in Florida at the time of her divorce from H-1. ${ }^{43}$ Nevertheless, the Court first presumed, ${ }^{44}$ over dissent, ${ }^{45}$ that $\mathrm{H}-1$ had appeared in the Florida proceedings (the record being silent on this point), and then held that $\mathrm{H}-2$ was bound by the Florida decree and, in effect, was precluded from showing the absence of domicile. ${ }^{46}$ Thus, Cook indicates that a bilateral decree of divorce based on a finding of domicile is invulnerable as to a stranger waging collateral attack; ${ }^{47}$ whatever interest he may have had in the marital res is conclusively barred.

It is diffcult, however, to understand the basis of this holding in Cook. The only indication given by the Court was its reasoning that:

${ }^{40}$ Consult authorities cited notes 12 and 13 supra.

4342 U.S. 126 (1951).

12 Brief for Respondent, at 2, 5-6, 8-10.

43 Transcript of Record, at 12-14. Upon remand the Vermont Supreme Court acquiesced to the presumption that $\mathrm{H}-1$ had appeared so the question of W's domicile became academic. Cook v. Cook, 117 Vt. 173, 86 A.2d 923 (1952).

${ }^{44}$ Cook v. Cook, 342 U.S. 126, 129 (1951): "A judgment presumes jurisdiction over the subject matter and over the persons." The Vermont Supreme Court had also recognized the lack of a finding on this point. Cook v. Cook, 116 Vt. 374, 378, 76 A.2d 593, 595 (1950).

${ }^{45}$ Justice Frankfurter differed with the majority only insofar as it presumed that silence in the record as to whether or not $\mathrm{H}-1$ had appeared in the Florida proceedings justified a presumption of appearance. Cook v. Cook, 342 U.S. 126, 132 (1951) ("And yet the Vermont. Supreme Court is reversed on the unwarranted presumption that Mann [H-1] appeared in the Florida suit."). He reasoned that since it was "inconceivable that the Vermont courts did not know that the fraudulent claim of domicile by a divorcing spouse is irrelevant to the enforceability in sister States of a decree of divorce if the other spouse contests or consents to the proceeding leading to the decree," then in annulling the marriage the Vermont courts must have found the Florida proceeding ex parte and, therefore, were competent to refuse full faith and credit to the Florida decree under the rule of Williams v. North Carolina II, 325 U.S. 226 (1945).

${ }^{46}$ Unless Florida would allow the second husband to attack the decree in Florida. Cook v. Cook, 342 U.S. 126, 128 (1951); Johnson v. Muelberger, 340 U.S. 581, 587 (1951).

${ }^{47}$ But compare Necessity For Domicile in Two-Party Divorces, 52 Col. L. Rev. 282, 283 (1952), which suggests, in spite of the Court's broad use of stranger, quoted in text at note 48 infra, that not all strangers are precluded by the holding of Cook v. Cook since there H-2's interest in the marital status had not accrued by the time W secured her divorce from H-1. Thus, if the Supreme Court wants to escape the full impact of its broad holding in the Cook case, it may confine the case as precedent to attacks by subsequent spouses. 
If the defendant spouse appeared in the Florida proceedings and contested the issue of the wife's domicile (Sherrer v. Sherrer, 334 U.S. 343) or appeared and admitted her Florida domicile (Coe \%. Coe, 334 U.S. 378) or was personally served in the divorce state (Johnson v. Muelberger, 340 U.S. 581, 587), he would be barred from attacking the decree collaterally; and so would a stranger to the Florida proceedings, such as respondent, unless Florida applies a less strict rule of res judicata to the second husband than it does to the first..$^{48}$ (Italics added.)

Alternative explanations may be offered for this intriguing language. It might imply that collateral attack upon a bilateral decree of divorce must fail because there is nothing in such a decree left open to attack. In other words, domicile-so long a basis of divorce jurisdiction-is no longer essential. ${ }^{49}$ While such a development may be foreseen, ${ }^{50}$ it is unlikely that the Supreme Court would discard its long-established requirement of domicile by implication, and there are subsequent indications by the Court that it has not. ${ }^{51}$

A sounder explanation is suggested by the Court's use of the term res judicata. Since it is clear that the scope of res judicata in actions in personam binds only parties and their privies ${ }^{52}$ and does not extend so far as to bind strangers, ${ }^{53}$ the Court must have meant that a divorce rendered pursuant to bilateral jurisdictional circumstance results in a decree akin to a judgment in rem. This does not explain, however, why attack for defect in jurisdiction, i.e., erroneous finding of domicile, is not permitted.

Though it was not cited by the Court, some technical justification for this extraordinary finality may be found in the comparatively ancient case of Cheever v. Wilson. ${ }^{54}$ It was held there "that a decree of divorce granted by a state in which one spouse was domiciled and which had personal jurisdiction over the other was as conclusive in the other state as it was in the state where it

${ }^{18}$ Cook v. Cook, 342 U.S. 126, 127-28 (1951).

49 This interpretation is suggested in Stimson, Jurisdiction in Divorce Cases: The Unsoundness of the Domiciliary Theory, 42 A. B. A. J. 222, 224 (1956).

${ }^{50}$ The tolerance with which the Court has viewed mere formal compliance with the present requirement of domicile (e.g., the remarks of Justice Frankfurter in note 61 infra), and the diminishing significance of real domicile which is the practical effect of such decisions as Coe v. Coe, 334 U.S. 378 (1948), and Sherrer v. Sherrer, 334 U.S. 343 (1948), suggest the eventual demise of that requirement. The voice of dissent has already been raised. Consult the remarks of Justice Rutledge and Judge Hastie in note 68 infra.

s1 See Granville-Smith v. Granville-Smith, 349 U.S. 1, 4, 15-16 (1955). Note also that when Justice Jackson, dissenting in May v. Anderson, 345 U.S. 528, 538 (1953), declared that he was "quite aware that in recent times this Court has been chipping away at the concept of domicile," he did not concede that the concept had been chipped away with respect to divorce jurisdiction but rather limited his proposition to a state's power to tax.

52 Good Health Dairy Products Corp. v. Emery, 275 N.Y. 14, 9 N.E.2d 758 (1937); Bernhard v. Bank of America, 19 Cal.2d 807, 812, 122 P.2d 892, 894 (1942) (" $\mathrm{He}$ is bound by that litigation only if he has been a party thereto or in privity with a party thereto."). Consult Rest., Judgments $\$ 79$ et seq. (1942); 10 Am. Law \& Proc., Judgments $\$ 41(1)$ (1912).

${ }^{53}$ See, e.g., Hansberry v. Lee, 311 U.S. 32, 40 (1940). Consult 1 Freeman, Judgments $\$ 407$ (5th ed., 1925); Rest., Judgments \$\$1, Comment e, 93 et seq. (1942).

549 Wall.(U.S.) 108 (1869). The facts are set forth in note 35 supra. 
was obtained." ${ }^{15}$ Cheever was decided long before Williams v. North Carolina $I$, during a period when something more than the ordinary domicile of one spouse was necessary for the compulsory recognition of sister-state ex parte decrees of divorce, viz., "matrimonial" domicile. ${ }^{56}$ Ordinary domicile alone conferred no power upon a divorce court to render a decree to which sister states were required to accord full faith and credit. ${ }^{57}$ In Cheever, however, when defendant's appearance was coupled with ordinary domicile, a jurisdiction matured which apparently was at least as conclusive as that produced by matrimonial domicile alone. Whether or not it was more conclusive, i.e., cut off the stranger's opportunity to impeach the decree by re-litigating the finding of domicile, was not answered since the stranger there had "reserve[d] to himself the right to impeach it if occasion should offer and require him to do so." ${ }^{158}$ Nevertheless, Cheever v. Wilson suggests that the appearance of the defendant spouse does not operate simply as a personal estoppel against him, but that it somehow joins the divorce court's finding of domicile of the plaintiff and produces a jurisdiction the product of which is unassailable, unlike the jurisdiction effectuated by the divorce court's impeachable finding of matrimonial domicile.

A further justification for the holding in Cook v. Cook may be suggested. It is best seen by comparing the effect of a bilateral decree with that of an ex parte decree. In the latter situation, where collateral attack is permitted for jurisdictional defect, the plaintiff's affirmative allegations of domicile in the divorce proceedings were unchallenged unless questioned by the court on its own motion. ${ }^{59}$ No litigant whose interest in regard to this issue is adverse to that of the plaintiff contested or even had an opportunity to contest the existence of domicile. But such an opportunity was presented ex hypothesi in the case of a bilateral decree. ${ }^{60}$ The defendant spouse, whose interest on the narrow issue of domicile is at least in theory adverse to that of the plaintiff and identical with that of strangers who may later desire to attack the decree, had full opportunity to contest the existence of domicile. Consequently, it may be concluded that since their point of view on the question of domicile has been represented in the original proceedings, ${ }^{61}$ strangers should not later be allowed to re-litigate the

${ }^{65}$ Williams v. North Carolina I, 317 U.S. 287, 296 (1942).

${ }^{56}$ Atherton v. Atherton, 181 U.S. 155 (1901). See Haddock v. Haddock, 201 U.S. 562 (1906). Consult Rheinstein, The Constitutional Bases of Jurisdiction, 22 U. of Chi. L. Rev. 775,775 n. 2 (1955).

s7 Haddock v. Haddock, 201 U.S. 562 (1906).

${ }^{58}$ Cheever v. Wilson, 9 Wall.(U.S.) 108, 122 (1869).

${ }^{9}$ E.g., Williams v. North Carolina II, 325 U.S. 226 (1945); Bell v. Bell, 181 U.S. 175 (1901); Streitwolf v. Streitwolf, 181 U.S. 179 (1901). Cf. Alton v. Alton, 207 F.2d 667 (C.A. 3d, 1953), cert. granted 347 U.S. 911 (1954), but mooted so dismissed, 347 U.S. 610 (1954). (1948).

${ }^{60}$ E.g., Coe v. Coe, 334 U.S. 378, 380-81 (1948); Sherrer v. Sherrer, 334 U.S. 343, 346

${ }_{61}$ The suggestion that a general denial entered by a cooperative defendant spouse constitutes an adequate representation of absent strangers with similar interests on the issue of domicile is acceptable in theory only. But the whole scheme of recognition of sister-state decrees of divorce is characteristically indulgent toward technically sound theoretical rules which are 
question. This amounts to treating the original finding of domicile as correct, which is of course the holding in Cook v. Cook.

In summary, one aspect of Cook results in a situation much like that of the typical judgment in rem-strangers being bound thereby although not parties or in privity with parties to the original proceedings. The inability of a stranger to attack the prior decree for jurisdictional defect, however, appears to differ from the general in rem situation. Nevertheless, if the reasoning discussed above as to the defendant spouse representing strangers' interests is accepted, it may be urged that even this aspect of Cook v. Cook is not inconsistent with a judgment in rem. ${ }^{62}$

The necessity of a finding of domicile remains to be discussed. Although there is no authority directly on point, recent cases indicate that a bilateral decree not based on a finding of domicile is not entitled to full faith and credit. ${ }^{63} \mathrm{It}$ is reasoned that such a decree violates due process of law where rendered, ${ }^{64}$ and consequently is not entitled to full faith and credit elsewhere. ${ }^{65}$ However, it is

embarrassed by reality. E.g.: "Sherrer v. Sherrer, supra, and Coe v. Coe . . were not puss-inthe-corner adjudications. It is inconceivable that the Vermont courts did not know that the fraudulent claim of domicile by a divorcing spouse is irrelevant to the enforceability in sister States of a decree of divorce if the other spouse contests or consents to the proceeding leading to the decree." (Italics added.) Cook v. Cook, 342 U.S. 126, 131-32 (1951) (Frankfurter, J., dissenting).

62 No case has been found dealing with collateral attack for jurisdictional defect by a claimant to the res where other claimants had already litigated jurisdiction in the original proceeding.

6s See Alton v. Alton, 207 F.2d 667, 674-75 (C.A. 3d, 1953), cert. granted 347 U.S. 911 (1954), but mooted so dismissed 347 U.S. 610 (1954); Jennings v. Jennings, 251 Ala. 73, 74-75, 36 So.2d 236, 238 (1948). But cf. Drew v. Hobby, 123 F.Supp. 245 (S.D.N.Y., 1954). An exception to the Alton view is found in two recent cases, both of which involve special circumstances. Crownover v. Crownover, 58 N.M. 597, 274 P.2d 127 (1954) (statute conclusively presuming domicile from one year's residence held valid in its purposed application to divorce of military personnel who, being under orders, should not be required to possess the requisite animi manendi el non revertendi - which are commonly said to be essential to domicile); DavidZieseniss v. Zieseniss, 205 N.Y.Misc. 836, 129 N.Y. S.2d 649 (S.Ct., 1954) (New York statute giving state courts jurisdiction to dissolve marriages solely upon the basis that the parties were married in New York held valid). Whether or not these decisions are correct, and what is the effect to be given decrees so issued are open questions. Consult Stimson, op. cit. supra note 49 .

64 Alton v. Alton, 207 F.2d 667 (C.A. 3d, 1953), cert. granted 347 U.S. 911 (1954), but mooted so dismissed 347 U.S. 610 (1954), holding that even where both parties are before the divorce court, the court could not render a decree, pursuant to the second part of a Virgin Islands' statute presuming domicile, without violating the Due Process Clause. The same Court of Appeals in Granville-Smith v. Granville-Smith, 214 F.2d 820 (1954), decided the same issue raised by identical facts, only to be affirmed on a different ground by the Supreme Court, 349 U.S. 1 (1955). Compare Jennings v. Jennings, 251 Ala. 73, 36 So.2d 236 (1948), where the Alabama Supreme Court, without mentioning due process of law, held that a statute allowing dissolution of marriages where both parties are before the court but without a finding of domicile exceeded the power of the state legislature. "[W]e say that the legislature of a state cannot confer on the courts of that state a power which is not within the power of the state to confer on the legislature." Ibid., at 75, 238.

${ }^{65}$ Judge Goodrich states that "[w]ith regard to this type of case one can generalize and say that due process of law at home and full faith and credit in another state are correlative." 
difficult to comprehend exactly how a party before the court in this situation is in any way deprived of "life, liberty, or property, without due process of law." It may thus be significant that this question was studiously avoided the only time it was presented to the Supreme Court. ${ }^{67}$

Nevertheless, assuming due process of law is satisfied by a bilateral proceeding without a finding of domicile, it does not necessarily follow that the decree will be entitled to full faith and credit. Although the finality of decrees would be enhanced, ${ }^{68}$ and the temptation for perjury reduced, ${ }^{69}$ the effect of compulsory interstate recognition would be to allow any one state to establish the divorce standards for the entire nation. ${ }^{70}$ Such a result runs counter to long

Alton v. Alton, 207 F.2d 667, 676 (C.A. 3d, 1953), cert. granted 347 U.S. 911 (1954), but mooted so dismissed 347 U.S. 610 (1954). Judge Hastie, dissenting, seemed to agree on this point: "Perhaps full faith and credit should be given to every American divorce decree which satisfies due process." Ibid., at 684. Judge Goodrich's view is correct where due process is violated, since full faith and credit is not required to be given to a nullity. See Williams v. North Carolina II, 325 U.S. 226, 227-29 (1945). But of course securing a judgment in full compliance with due process of law does not assure that it will be given full faith and credit. See Haddock v. Haddock, 201 U.S. 562 (1906). Consult Currie, Full Faith and Credit to Foreign Land Decrees, 21 U. of Chi. L. Rev. 620, 667 n. 166 (1954).

${ }^{66}$ U.S. Const. Amend. 14, \$1. Consult Rheinstein, op. cit. supra note 56; Griswold, Divorce Jurisdiction and Recognition of Divorce Decrees-A Comparative Study, 65 Harv. L. Rev. 193, 197-208 (1951).

${ }^{67}$ In Granville-Smith v. Granville-Smith, 349 U.S. 1, 26 (1955), the Supreme Court stated that a Virgin Islands' statute which created a presumption of domicile was "designed for export" and thus was not within the power delegated to the Islands' Legislative Assembly by Congress. The dissent thought that "[t]here are limits to which the Court should not run to escape a constitutional adjudication. ... Nevertheless, the Virgin Islands are entitled to a forthright adjudication on their statute-not one by a phantom escape clause."

${ }^{68}$ The vulnerable point of a divorce decree at which an attack is launched is the jurisdictional finding of plaintiff's domicile. If a finding of domicile is held unnecessary to the decree for purposes of full faith and credit, then a stranger would have nothing to attack, except, of course, the fact that defendant appeared. A hint at the elusiveness of a finding of domicile and perhaps the reason for some judicial displeasure with the concept of domicile are seen, for example, in Justice Rutledge's strong dissent in Williams v. North Carolina II, 325 U.S. 226, 255 (1945): "The Constitution does not mention domicile. Nowhere does it posit the powers of the states or the nation upon that amorphous, highly variable common-law conception." Judge Hastie appears to agree in his dissent in Alton v. Alton, 207 F.2d 667, 681 (C.A.3d, 1953), cert. granted 347 U.S. 911 (1954), but mooted so dismissed 347 U.S. 610 (1954): "My conclusion is that ... the limitation of the divorce power to the domiciliary state has no such ancient roots or impressive history as to suggest its entitlement to perpetuation as a constitutional requirement." But compare the language of Justice Frankfurter in note 71 infra.

${ }^{69}$ See Granville-Smith v. Granville-Smith, 349 U.S. 1, 28 (1955); Sherrer v. Sherrer, 334 U.S. 343, 356-57 (1948). Consult Rheinstein, op. cit. supra note 66, at 776.

${ }^{70}$ See Sherrer v. Sherrer, 334 U.S. 343, 366 (1948); Haddock v. Haddock, 201 U.S. 562, 574 (1906). It will be noted that the holding in Cook v. Cook, 342 U.S. 126 (1951), comes perilously close to being subject to the objection stated in the text. If a mere finding of domicile in a bilateral proceeding operates so as to preclude collateral attack, it is possible for non-domiciliary parties through collusion to obtain a divorce decree which will be valid in other states. Defendant need only admit plaintiff's affirmative allegations. Coe v. Coe, 334 U.S. 378 (1948). Theonly protection against such procedure is the divorce court, which can as a general rule raise the question of domicile on its own motion. This is sometimes done. Consult Alton v. Alton, 207 F.2d 667 (C.A.3d, 1953), cert. granted 347 U.S. 911 (1954), but mooted so dismissed 347 U.S. 610 (1954). 
accepted doctrine. ${ }^{71}$ However, if compulsory recognition were not required this would create a situation analogous to that which followed Haddock v. Haddock ${ }^{72}$ -a decree being valid where rendered and yet not entitled to full faith and credit elsewhere. Thus, the evils which led to the rejection of Haddock in Williams $I^{73}$ militate against approval of a situation whereby a valid decree is denied full faith and credit. Alternatively, these same evils may well lead to an acceptance of the position that a bilateral decree not based on a finding of domicile violates due process of law. ${ }^{74}$ And it is clear that full faith and credit need not be given to such a decree. ${ }^{75}$

The major unsettled question in the context of stranger attack on sisterstate divorce decrees concerns attack by a state on an out-of-state bilateral decree. Could Vermont convict Mrs. Cook of bigamous cohabitation ${ }^{76}$ by claiming that her divorce from Mr. Mann was invalid, even though Mr. Cook was unsuccessful in his annulment action based on a similar claim? The weight of authority is in the negative. ${ }^{77}$

Proper analysis of this question raises a preliminary inquiry. As a general rule, full faith and credit requires that all states give a sister state's judgment the same force and effect as it has in the state of its rendition..$^{78}$ For example,

${ }^{71}$ Justice Frankfurter states the traditional view in Williams v. North Carolina II, 325 U.S. 226, 229 (1945): "Under our system of law, judicial power to grant a divorce-jurisdiction, strictly speaking-is founded on domicil. Bell v. Bell, 181 U.S. 175; Andrews 0. Andrews, 188 U.S. 14. The framers of the Constitution were familiar with this jurisdictional prerequisite, and since 1789 neither this Court nor any other court in the English-speaking world has questioned it. Domicil implies a nexus between person and place of such permanence as to control the creation of legal relations and responsibilities of the utmost significance." For the contrary view consult note 68 supra.

72201 U.S. 562 (1906).

${ }^{73}$ These evils were foreseen by Justice Holmes in his dissent therein: "[T]he decision not only reverses a previous well-considered decision of this court but is likely to cause considerable disaster to innocent persons and to bastardize children hitherto supposed to be the offspring of lawful marriage. ..." Haddock v. Haddock, 201 U.S. 562, 628 (1906). Consult Overton, Sister State Divorces, 22 Tenn. L. Rev. 891,896 (1953).

74 The dilemma posed by the preceding discussion is suggested in Currie, op. cit. supra note 65 , at $667 \mathrm{n}$. 166. In substance it is this: Given bilateral proceedings, domicile is or is not required for due process of law. If it is, technical justification is difficult. If it is not, and if full faith and credit is given to the resultant decree, then the lowest common denominator in divorce laws may become the law throughout the country (at least as to bilateral divorces). But if full faith and credit is not given, then the evils of the Haddock case reappear. Thus, every alternative seems undesirable-the least so appearing to be retention of the domicile requirement, since it presents only difficulties in legal theory, and not in practical effect.

${ }^{75}$ Consult discussion note 65 supra. $\quad{ }^{76} \mathrm{Vt}$. Rev. Stat., c. $370, \$ 8470$ (1947).

77 Hack v. Industrial Commission, 74 Ariz. 305, 248 P.2d 863 (1952); State v. Foster, 5 Ter.(Del.) 384, 57 A.2d 58 (1948). Cf. Drew v. Hobby, 123 F.Supp. 245 (S.D.N.Y., 1954). Contra: Lipham v. State, 68 Ga. App. 174, 22 S.E.2d 532 (1942); Goodrich, Conflict of Laws 401 (3d ed., 1949).

78 "Such Acts, records and judicial proceedings or copies thereof, so authenticated, shall have the same full faith and credit in every court within the United States and its Territories and Possessions as they have by law or usage in the courts of such State, Territory or Possession from which they are taken." 62 Stat. 947 (1948), 28 U.S.C.A. \$1738 (1950). 
in Johnson v. Muelberger ${ }^{79}$ and $C_{0 o k}$ v. Cook, ${ }^{80}$ reference was made to the law of Florida as the measure of the binding effect of Florida decrees in other states. However, since the issue of the effect of a Florida decree in other states cannot arise in Florida, Florida can have no law directly on point. Thus, these cases must mean that the law of the state of rendition is determinative of the scope of full faith and credit only insofar as it indicates the result which would obtain if the attack had been brought in the rendering state. Conversely, the state of rendition can have no law relevant to the question of full faith and credit where the attack is of such a nature that it could not in the first instance be waged in the courts of the rendering state. This situation is clearly presented when a decree is attacked by a sister state in a prosecution for bigamous cohabitation, for it is obvious that the sister state could not have prosecuted its charges in the state of rendition. In such circumstances, it is suggested that federal law should control the interstate effect of the decree. ${ }^{81}$

In support of the view that Vermont as a matter of federal law could not succeed in its prosecution of Mrs. Cook, it may be urged that no basis is apparent under the holding of Cook v. Cook upon which to distinguish the position of a sister state from that of strangers generally. No distinction obtains in the ex parte situation under the rule in Williams $I$, which would seem to indicate that a sister state has no peculiar interest demanding special treatment. In fact, any inequality of interest deemed to exist may well weigh in favor of natural-person strangers because of the protection afforded the latter by the Due Process Clause. ${ }^{82}$

To the contrary it may be argued that the requirements of our federal system demand some basis for the frustration of a sister state's policy beyond mere physical presence of the parties to the bilateral proceedings. ${ }^{83}$ Thus, historically, some connection of the parties to the divorce state-typically domicile-has been necessary as a basis for divorce jurisdiction. ${ }^{84}$ To preclude a sister state from showing the absence of domicile can therefore only encourage collusion ${ }^{85}$

79340 U.S. 581 (1951).

${ }^{80} 342$ U.S. 126 (1951).

${ }^{81}$ Cf. Huntington v. Attrill, 146 U.S. 657 (1892) (whether judgment of sister state was based upon penal cause of action and so might be denied full faith and credit a matter of federal law, regardless of how it was characterized by that state); Bigelow v. Old Dominion Copper Co., 225 U.S. 111, 139 (1912) (whether judgment dismissing bill against one joint tortfeasor is bar to suit against the other in a sister state is a matter of full faith and credit to be determined "under the general law" [only federal precedents utilized], although it was such a bar in the state where rendered).

82 U.S. Const. Amend. 14, \$1 ("... nor shall any State deprive any person of life, liberty, or property without due process of law ..."). (Italics added.)

${ }^{83}$ Consult, e.g., Williams v. North Carolina II,.325 U.S. 226, 229 (1945).

84 Ibid.

${ }^{85}$ There was clear evidence of just this type of collusion to secure a divorce in Cook v. Cook, 342 U.S. 126, 126-27 (1951). However, the Court did not rule upon the question of whether or not Mr. Cook could be estopped because of the collusion since that issue was not raised. Cook v. Cook, 116 Vt. 374, 76 A.2d 593 (1950). But there is authority supporting the 
and consequent successful evasion of the divorce laws of the state of actual domicile. ${ }^{86}$ Final decision of this difficult question awaits a determination by the Supreme Court.

If a state does fall within the term siranger as used in Cook v. Cook, ${ }^{87}$ then a symmetry between stranger attack and party attack exists in the bilateral area as it does in regard to an ex parte decree. ${ }^{88}$ Where the defendant spouse was within the personal jurisdiction of the court and had an opportunity to litigate the allegation of domicile, ${ }^{89}$ he is thereafter conclusively bound by the finding of domicile. ${ }^{90}$ And, where parties are bound by the bilateral decree, so also are strangers. The chink in the armor of an ex parte decree-impeachable finding of domicile-appears to clamp shut with the thaumaturgic touch of a cooperative defendant spouse who submits to the personal jurisdiction of the court. At the very least this result may lay claim to the virtue of greater certainty upon which interested persons may rely. And, as much as it may be deplored by those who fear that undue prejudice may accrue to strangers conclusively bound by the decree, ${ }^{91}$ the result may perhaps be made more palatable by treating some of the interests of strangers as rights in personam in order that they may obtain the same protection available to the spouse absent from an ex parte divorce proceeding under the doctrine of divisibility.

view that Mr. Cook could be precluded on that ground alone. E.g., Estate of Coleman, 132 Cal.App.2d 137, 281 P.2d $56 \%$ (1955).

${ }^{86}$ No case has been found illustrating attack by a non-domiciliary state. But cf. Drew v. Hobby, 123 F.Supp. 245 (S.D.N.Y., 1954).

87342 U.S. 126, 127 (1951).

88 Consult discussion at 380 supra.

${ }^{80}$ Consult authorities cited note 36 supra. The divorce decree "by default" is an open question, i.e., does the doctrine of Coe v. Coe, 334 U.S. 378 (1948), and Sherrer v. Sherrer, 334 U.S. 343 (1948), extend so far as to include the case where the defendant spouse was merely served with process but failed to appear either personally or through an attorney? The question will probably be answered in the affirmative. See, e.g., Cook v. Cook, 342 U.S. 126, 128 (1951): "On the other hand, if the defendant spouse had neither appeared nor been served in Florida, the Vermont court, under the ruling in Williams v. North Carolina, 325 U.S. 226, could reopen the issue of domicile."

90 Coe v. Coe, 334 U.S. 378 (1948); Sherrer v. Sherrer, 334 U.S. 343 (1948); Davis v. Davis, 305 U.S. 32 (1938). Compare Cook v. Cook, 342 U.S. 126 (1951).

${ }^{91}$ Consult, e.g., Merrill, The Utility of Divorce Recognition Statutes in Dealing with the Problem of Migratory Divorce, 27 Tex. L. Rev. 291, 311 (1949); Toward Certainty in the Extraterritorial Effect of Divorce Decrees, op. cit. supra note 37. But compare Necessity for Domicile in Two-Party Divorces, op. cit. supra note 47 , for a favorable view. 